\title{
KOTA, RUANG, DAN POLITIK KESEHARIAN: Produksi dan Konsumsi Ruang Bersenang-senang dalam Geliat Yogyakarta
}

\author{
Ali Minanto \\ Prodi Komunikasi Universitas Islam Indonesia \\ Jalan Kaliurang KM. 14,5 Sleman, Yogyakarta 55584 \\ Email: ali.minanto@uii.ac.id
}

\begin{abstract}
Abstrak
Kota tumbuh bersama paradoks yang menyertainya. Di satu sisi, kota menyodorkan mimpi-mimpi, menjadi ruang magnetik yang menyedot siapa saja untuk terserap di dalamnya. Namun, di lain sisi ia menjelma mesin penggilas segala hasrat dan imajinasi tentang keindahan, kesejahteraan, dan kemakmuran yang hidup dalam benak orang banyak. Yogyakarta, kota yang menyandang banyak predikat terus mengalami perubahan. Sebagai ruang yang memperjumpakan kepelbagaian, Yogyakarta mulai berbenah dengan menyajikan situs-situs konsumerisme baru yang berpotensi menyingkirkan ruang-ruang publik. Reduksi terhadap ruang publik menstimulasi hadirnya ruang-ruang alternatif sebagai ruang publik baru sekaligus destinasi dari eskapisme warga untuk menemukan kesenangan (space of enjoyment). Tulisan ini ingin melihat bagaimana ruang-ruang alternatif di Yogyakarta diproduksi, dikonsumsi, dan bersalinrupa menjadi ruang bersenang-senang warga kota.
\end{abstract}

Keywords: Kota, Yogyakarta, Ruang bersenang-senang

\begin{abstract}
The city grows with its paradox. On the one hand, the city offers dreams, into magnetic spaces that suck anyone to be absorbed in it. However, on the other hand, it becomes the engine to crush all desires and imagination about beauty, well-being, and prosperity that live in the minds of people. Yogyakarta, a city that has many predicates, continues to change. As a space where many different identities live together, Yogyakarta begins to improve by presenting new consumerism sites that have the potential to get rid of public spaces. Reduction of public space stimulates the presence of alternative spaces as a new public space. It will be a destination for citizen escapism to find space of enjoyment. This article wants to see how the space of enjoyment as alternative spaces in Yogyakarta are produced and consumed by the citizens of Yogyakarta.
\end{abstract}

Keywords: City, Yogyakarta, Space of Enjoyment 


\section{Pendahuluan}

Yogyakarta sebagai kota yang mempertemukan kepelbagaian menjadi ruang yang dinamis dan selalu bersolek. Perjumpaannya dengan beragam entitas menyebabkan Yogyakarta menjadi kota yang terbuka terhadap multi gagasan dan pemikiran. Sebagai sebuah kota, Yogyakarta juga tumbuh dengan mistisisme yang bermuara pada kesadaran akan pentingnya perbedaan dan pertentangan (Mas'oed, Panggabean, Azca 2007: 199-200). Yogyakarta menjadi kota yang hadir dengan sebuah paradoks, yang memadukan antara yang tenang dan yang bergerak. Di satu sisi, Yogyakarta menjunjung tinggi budaya ke-Jawa-an yang memiliki komitmen kepada kesabaran, ketenangan, dan moderasi. Namun di sisi lain, Yogyakarta juga dikenal sebagai ruang yang menumbuhkan pelbagai perlawanan revolusioner. Dalam catatan sejarah, berbagai peristiwa politik besar terjadi di kota ini. Di sinilah, watak Yogyakarta sebagai sebuah kota yang dinamis menarik untuk diperbincangkan.

Transformasi ruang perkotaan yang berlangsung di Yogyakarta dalam satu dekade terakhir menunjukkan perubahan tata ruang kota yang radikal. Hadirnya ruang-ruang konsumerisme seperti pusat perbelanjaan, destinasi wisata, resto, kafe, sarana olahraga, dan lainnya, menunjukkan dinamika perubahan tata ruang kota yang cukup signifikan (PBB, 1995; Yusuf, 2006). Portal Gudeg.net merilis perubahan Yogyakarta dengan 243 objek tujuan wisata, 104 tempat berbelanja (di dalamnya supermarket dan hypermarket), 231 tempat wisata kuliner, 731 hotel dan penginapan. Perubahan ini setidaknya menimbulkan beberapa persoalan. Pertama, munculnya ruangruang konsumerisme mengakuisisi keberadaan ruang publik. Kedua, komodifikasi ruang kota berandil dalam pembentukan kebutuhan dan selera baru masyarakat yang cenderung konsumtif. Ketiga, ruang-ruang baru dengan segala aturan mainnya menyingkirkan kelompok masyarakat tertentu yang tidak sanggup beradaptasi.

Ruang kota diorientasikan menjadi space of enjoyment (ruang kesenangan atau ruang bersenang-senang) yang memberi harapan dan mimpi-mimpi kebahagiaan warganya. Namun, kota kerap menampakkan wajahnya yang ambigu. Pada satu sisi, kota menawarkan mimpi, menjadi ruang magnetik yang bisa menarik siapa saja untuk datang dan bersemayam di dalamnya, tapi, di sisi lain, kota juga sebuah mesin penggerus segala hasrat dan imajinasi tentang keindahan, kesejahteraan, kemakmuran, dan kemerdekaan yang diangankan oleh orang kebanyakan. Bahkan, kota siap mencampakkan siapa saja yang tidak sanggup bersaing untuk berebut "ruang kekuasaan”. Kelompok berkuasa, para pemilik otoritas, menggunakan kekuasaannya untuk menata ruang-ruang kota sebagai sarana kontrol sosial (Fiske, 1995: 36). Melalui ruang-ruang kesenangan, identitas dan selera publik diracik dan dirumuskan ulang. Dalam lanskap masyarakat konsumtif, yang memandang konsumsi sebagai habitus dan gaya hidup, kota dianggap sebagai panggung tontonan raksasa yang tidak pernah tandas untuk dinikmati. Tata ruang perkotaan perlahan menginterpelasi dan membentuk selera publik. Pusat-pusat perbelanjaan, kafe, resto, game center, biro-biro travel, paket-paket turisme, dihadirkan sebagai arena untuk memenuhi selera dan kebutuhan "baru" masyarakat.

Kapitalisasi dan komodifikasi ruang perkotaan selain menawarkan nilainilai hedonisme juga meneguhkan disparitas kelas dan mengokupasi ruang publik. Akibatnya, publik kota harus 
kehilangan ruang aktualisasi kepublikan dan peran kewargaannya direduksi menjadi sekadar konsumen. Tata ruang kota berusaha mendisiplinkan pola relasi warga dalam logika yang transaksional. Ruang-ruang kesenangan yang ada berisiko menyingkirkan kelompok masyarakat tertentu, khususnya kelas menengah bawah (lower middle class) dan kalangan miskin kota (lower class/urban poor). Mereka yang tidak memiliki modalitas ekonomi yang cukup untuk menjadi konsumen aktif. Ini berarti bahwa mereka tersingkir karena tidak sanggup terlibat dalam "aturan main" yang dibuat oleh kelompok berkuasa (tatanan simbolik).

Sebagai destinasi wisata (tourism area) yang cukup terkenal, Yogyakarta melakukan banyak pembenahan tata ruang kota dalam beberapa tahun terakhir. Hal ini ditandai dengan hadirnya ruang-ruang turisme baru yang tersebar di beberapa wilayah di Yogyakarta. Sayangnya, dinamika Yogjakarta tersebut direspons oleh pemerintah kota dengan melakukan pembangunan infrastruktur yang sangat masif dan tidak terkontrol, terutama pembangunan hotel, pusat perbelanjaan (mall), dan apartemen. Ada beberapa rancangan regulasi pemerintah kota yang dianggap tidak pro publik. Dalam beberapa tahun terakhir, pemerintah setempat telah memberikan izin pembangunan 106 hotel baru yang sudah siap dibangun, 15 pusat perbelanjaan superbesar (hypermarket), dan apartemen di beberapa kawasan. Kebijakan ini menuai banyak protes, dan dianggap sebagai kegagalan pembuat kebijakan dalam mengatur tata ruang kota. Beberapa aksi unjuk rasa digelar untuk memprotes kebijakan ini. Isu yang muncul tidak hanya menyempit dan lenyapnya ruang publik karena dikooptasi ruangruang konsumerisme baru, tapi juga terkait dengan persoalan lingkungan, seperti akses air bersih bagi warga. Hotel dan supermarket menyerap banyak air tanah yang sangat dibutuhkan masyarakat di samping memproduksi limbah. Selain itu, hadirnya supermarket yang terlalu masif juga dikwatirkan akan menstimulasi hasrat konsumeristik dan gaya hidup hedonistik masyarakat Yogyakarta.

Wajah Janus kota menciptakan dilema sehingga perubahannya dirindukan sekaligus dikecam. Banyak kisah penolakan warga terhadap pembangunan tata ruang kota sebagaimana terjadi di Yogjakarta. Tidak sedikit warga Yogyakarta yang melayangkan protes, keberatan terhadap pembangunan situs-situs konsumerisme yang mulai menjamur. Warga Yogyakarta pernah melakukan gugatan terhadap manajemen Saphier Square karena supermarket yang berada di Jalan Solo itu menyebabkan kerusakan lingkungan. Beberapa pembangunan apartemen juga menjadi target protes warga Yogyakarta, seperti protes terhadap pembangunan apartemen Uttara the Icon di jalan Kaliurang KM 5 Sleman pada tahun 2014. Penolakan dipicu oleh beberapa alasan: ancaman terhadap ketersediaan air tanah, munculnya budaya hedonis, memperparah kemacetan, risiko kecelakaan kerja (keamanan, peralatan). Ada kecurigaan perusahaan pengembang sengaja mengobarkan konflik horizontal antar warga perihal penerimaan keberadaan apartemen (tirto, 10 Juli 2017). Penolakan pembangunan apartemen juga terjadi di wilayah kota, tepatnya di Balirejo Timoho di mana warga memprotes pembangunan Puri Notoprojo.

Relasi konfliktual ini menunjukkan tanda-tanda adanya malpraktik yang kerap terjadi dalam kebijakan tata ruang kota. Begitu juga dengan pembangunan ruang turisme di kawasan-kawasan "eksternal" (wisata pantai, gunung, dan wisata alam lain) seringkali memantik banyak perselisihan. Transformasi ruang natural menjadi destinasi wisata telah mengasingkan warga dari habitusnya. 
Ruang wisata memiliki tata aturan yang mendisiplinkan dan memaksa masyarakat untuk tunduk dalam habituasi baru. Relasi antara masyarakat dan ruang hidupnya, pada akhirnya, dikontrol oleh mekanisme industrial dengan logika kapitalistik.

Ditutupnya Purawisata yang pernah menjadi tujuan wisata "alternatif" bagi kalangan menengah (bawah) Yogyakarta merupakan imbas kebijakan tata ruang yang timpang. Terhitung sejak pertengahan 2013, Purawisata, situs penting bagi pecinta hiburan rakyat, ditutup setelah 24 tahun "menggoyang" Yogyakarta. Purawisata yang juga dikenal sebagai Tempat Hiburan Rakyat (THR) digusur, dan rencananya akan beralih rupa menjadi kawasan perhotelan. Fenomena penonaktifan Purawisata tidak sekadar menunjukkan kontestasi dalam perebutan ruang kota, tapi juga mengindikasikan upaya eksklusi terhadap kelompok masyarakat menengah bawah dan masyarakat miskin kota yang selama ini menjadi penonton setia hiburan murah meriah itu. Hiburan di Purawisata tergolong sangat murah karena hanya dengan membayar Rp 20 ribu, kelompok ini dapat mengurai kepenatan hidup dan menemukan ruang kesenangan alternatif. Selain Purawisata, beberapa situs kebudayaan lain juga mengalami nasib serupa seperti Seni Sono yang terletak di kawasan Titik Nol Kilometer. Seni Sono dikenal sebagai tempat ngumpul para seniman untuk berkreasi. Selain itu, juga ada Taman Kota di daerah Gondomanan, sebuah ruang publik dan ruang terbuka hijau bagi warga Yogyakarta yang pada 1998 berubah fungsi menjadi Taman Parkir Senopati.

Secara khusus, studi ini akan mencermati perkembangan tata ruang kota di Yogyakarta dalam konteks urban politics (Cochrane, 2010: 103), khususnya aktus politik keseharian (everyday life politics) warga dalam mengonsumsi (sekaligus memproduksi) ruang kesenangan (space of enjoyment). Tulisan ini juga akan melacak bagaimana proses kreasi produksi dan konsumsi ruang ruang kesenangan alternatif berlangsung di beberapa titik di Yogyakarta.

Riset ini menggunakan beberapa pendekatan konseptual. Pertama, jouissance atau konsep bersenang-senang yang dapat ditemukan dalam gagasan Slavoj Zizek. Bagi Zizek, kesenangan (jouissance/enjoyment) menjadi spirit dan orientasi yang menggerakkan rutinitas warga. Slavoj Zizek mengembangkan konsep jouissance Lacanian sebagai kesenangan, yang dalam kadar tertentu (beyond the limit) justru menyisakan rasa sakit (diistilahkan sebagai "pleasure in pain”), sebagaimana kesadaran palsu dalam terminologi Marxian untuk menggambarkan situasi ketika kapitalisme menenggelamkan subjek dalam infernal circuit of demand. Itulah sebabnya jouissance seringkali diartikan sebagai kenikmatan yang datang setelah kehilangan, sebagaimana seorang bayi yang berpisah dari kenikmatan asali saat berada di kandungan ibu. Jouissance dimaknai Zizek sebagai persimpangan super-ego yang selalu tunduk di bawah kekuasaan Sang Lain Besar (the Big Other). Sang Lain Besar adalah sosok yang terus mengawasi, menertibkan, dan memberi keputusan apakah subjek bisa menjadi subjek ideal (real subject). Kapitalisme kontemporer yang menawarkan kebebasan (liberalisme), dalam tatapan Zizek, hanya melakukan bujuk rayu yang pada akhirnya akan melanggengkan penindasan dari Sang Lain Besar. Kota merancang tatanan simbolik untuk menciptakan kegairahan, keteraturan sekaligus menjadi mesin pengontrol atas segala aktivitas publik melalui ruang-ruang kesenangan: destinasi turisme, pusat perbelanjaan, dsb 
Kedua, konsep kelas menengah menarik untuk disematkan dalam diskursus ruang perkotaan, terutama berkait dengan hasrat konsumerisme. Konsumerisme ekuivalen dengan tumbuhnya kelas menengah (baru) di perkotaan. Fenomena munculnya kelas menengah baru di Indonesia yang berkelindan erat dengan laku konsumtif tidak lagi cukup dimaknai sebagai gaya hidup untuk sekedar merepresentasikan pesan simbolik (symbolic values) yang mengisyaratkan status dan kelas sosial tertentu, tetapi juga berpengaruh dalam praktik kewargaan. Daniel Dhakidae (2012) mengafirmasi posisi kelas menengah dalam kaitannya dengan gaya hidup. Menurut Dhakidae, gaya hidup akan muncul ketika seseorang telah terlepas dari beban kebutuhan pokok. Konsumerisme menjadi 'pelarian' untuk melampiaskan hasrat hedonistik demi membangun gaya hidup tertentu. Kelas menengah merupakan kelompok yang secara dinamis akan terus memperbaharui seleranya. Inilah yang menyebabkan kelas menengah dianggap sebagai hasil persilangan antara kelas atas dan kelas di bawahnya. Geertz (1989) menyebutnya sebagai kelompok "berkaki dua", ambigu. Meskipun mereka mengonsumsi barangbarang berkelas, tapi tetap "mencontek" gaya hidup kelompok di atasnya. Upaya meniru kelas atas sebenarnya penuh kendala karena kelas atas selalu menciptakan distinction ketika kelompok di bawahnya berusaha meniru.

Ketiga, everyday politics. Kota konsumerisme bagi kalangan menengah namun juga kelompok yang dianggap marjinal dan subordinat. Fiske (2011: 39) menjelaskan bahwa produktivitas konsumsi tidak dibatasi oleh perbedaan kelas sosial. Seringkali, orang miskin adalah konsumen paling produktif. Kelompok masyarakat yang tidak sanggup menikmati paket turisme, berbelanja di pusat perbelanjaan, mengakses sekolah berkualitas, tetap berpretensi untuk menyalurkan hasrat konsumtifnya. De Certau (1984: 18) mengenalkan perlawanan populer yang dilakukan dengan cara "adaptasi" yang dalam kadar tertentu dimaknai sebagai 'tipu daya' dan 'pengecohan'. Salah satunya melalui praktik politik keseharian. Senada dengan Certau, Lafebvre (1971: 35) dalam "Everyday Politics in the Modern World", menggambarkan daya tahan masyarakat dalam menghadapi persoalan-persoalan hidupnya. Menurutnya, politik keseharian merupakan mekanisme yang dilakukan oleh tubuh untuk menghadapi himpitan kebutuhan dan tuntutan pemenuhan kesenangan. Itulah sebabnya Highmore (2002:3) menganggap politik keseharian sebagai aktivitas yang penuh misteri, "The everyday is also the home of the bizzare and mysterious. The commonplace of existence are filled with strange occurrences." Pendekatan everyday politics digunakan untuk membaca fenomena kota ketika ruang kesenangan diciptakan sebagai bentuk perlawanan diam-diam dalam memperebutkan ruang.

Keempat, Kota sebagai ruang bersenang-senang. Menurut Henry Lefebvre, setiap orang memiliki hak atas kota (Lefebvre, 1996). Kota dimaknai sebagai ruang yang memungkinkan terjadinya interaksi dan perubahan sosial, yag disebut Lefebvre sebagai "social centrality”. Henri Lefebvre (1991), dalam the Production of Space, mengenalkan pandangannya tentang ruang dalam kaitannya dengan pembentukan interaksi sosial atau sebaliknya. Ruang spasial membentuk cara berpikir yang berpengaruh pada pola interaksi sosial yang berlangsung. Dalam hal ini, produksi spasial menentukan produksi sosial yang terlihat dari cara berpikir dan bertindak. Lefebvre mengungkapkan, 
(Social) space is a (social) product ... the space thus produced also serves as a tool of thought and of action; that in addition to being a means of production it is also a means of control, and hence of domination, of power" (1991, 2627)

Merujuk Lefebvre, ruang tidak hanya ajang berinteraksi, tapi menjadi alat yang digunakan untuk menciptakan kontrol dan dominasi. Konstruksi ruang menjadi sarana untuk membentuk pemikiran dan tindakan.

Lefebvre membuat rumusan yang disebut sebagai " a conceptual triad of social space production”. Triadik konsep atas ruang dirumuskan Lefebvre sebagai berikut: a) praktik spasial (Spacial Practices), yang dipahami sebagai "lived space", ruang yang dihidupi. Konsep ini menunjukkan kohesi sosial atas suatu ruang ditentukan oleh derajat kompetensi dan kinerja dalam mengonsumsi ruang.

Praktik spasial mengacu pada produksi sekaligus reproduksi hubungan spasial antar objek sehingga menjamin keberlangsungan produksi ruang sosial dan relasinya. Produksi spasial menunjukkan interaksi dalam jejaring komunikasi, produksi, dan pertukaran yang berlangsung dalam kehidupan seharihari ; b) Representasi Ruang (Representation of Space), berkenaan dengan pengetahuan, kode, tanda, dan pemaknaan atas ruang. Ruang dikonsepsikan dan diperuntukkan berdasarkan aktivitas tertentu sehingga ada ruang untuk ilmuwan, seniman, masyarakat, dan sebagainya. Representasi Ruang melalui pelbagai citra dan konseptualisasi mengapa sesuatu dimaknai sebagai ruang. Ruang menjadi kajian yang memunculkan beberapa bidang pengetahuan: arsitektur, tata kota, geografi, dsb. Oleh karena itu, Representasi ruang identik dengan ruang yang dipersepsikan (perceived space); c)
Ruang Representasional (Representational Space), kebalikan representasi ruang, ruang representasional merupakan dimensi simbolik sebuah ruang. Ruang seringkali merujuk pada kekuatan dan kekuasaan adikodrati yang berada di luar ruang. Hal ini nampak pada hadirnya monument, artefak, tugu, dll.

\section{Metode}

Riset ini menggunakan metode observasi, studi dokumen, dan field research melalui wawancara mendalam dengan beberapa informan yang menjadi subjek dari ruang kesenangan alternatif yang muncul di Yogyakarta. Wawancara dilakukan dengan informan terpilih yang 'mewakili' subjek-subjek di beberapa wilayah kesenangan di Yogyakarta seperti Malioboro, Lempuyangan, dan juga alunalun kidul. Data yang terkumpul dari penelitian lapangan ini akan 'didialogkan' dengan konsep yang digunakan dalam penelitian ini sebagaimana telah dijelaskan sebelumnya.

\section{Analisis Dan Pembahasan}

Di tengah laju perubahan Yogyakarta yang drastis, masih ada usaha untuk merawat ruang-ruang kesenangan yang muncul secara organik maupun artifisial. Beberapa titik di Yogyakarta menjadi area destinasi wisata alternatif yang 'murah meriah', seperti kawasan trotoar Malioboro, Alun-alun Kidul, pinggir rel Lempuyangan, dan beberapa wilayah perdesaan yang menjadi ruang ekspresi artistik. Riset ini akan menceritakan beberapa pengalaman warga kota (juga desa - pinggiran kota) dalam memproduksi sekaligus mengonsumsi ruang-ruang kesenangan itu.

Malioboro masih menjadi pilihan favorit warga Yogyakarta sebagai destinasi wisata. Dalam beberapa masa terakhir, area ini mengalami pembenahan tata 
ruang. Pembenahan yang dilakukan di antaranya penataan kawasan parkir yang dijauhkan dari pusat keramaian sehingga trotoar di sepanjang jalan Malioboro hanya diperuntukkan bagi pengunjung yang ingin menikmati suasana kawasan ini. Sebagaimana diungkapkan Indri, mahasiswa asal Lampung, yang mulai jatuh cinta pada Yogyakarta terutama Malioboro. Menurutnya, kawasan Malioboro sangat menyenangkan dan tidak membuat bosan. Sepanjang trotoar diberi sentuhan artistik berupa karya instalasi, patung, dan tempat duduk untuk menikmati keriuhan kota. Selain itu, Malioboro juga dipilih karena lebih murah dibanding tempat lain baik untuk kuliner maupun suvenir yang dijajakan. Berbeda dengan mall atau supermarket yang terbatas jam buka, dia dapat menikmati Malioboro sepanjang waktu.

Letaknya yang strategis juga memudahkan bagi siapapun untuk menjangkau kawasan ini. Beberapa aktivitas yang dilakukan adalah sekadar jalan-jalan, selfie di beberapa titik yang menarik, menikmati denyut kehidupan Malioboro, menonton atraksi seniman jalanan, menikmati karya-karya istalasi seniman yang terpajang di sepanjang trotoar. Selain Malioboro, Indri juga kerap menyambangi Alun-alun Kidul yang terletak di sisi belakang Kraton Yogyakarta. Di sana, ia dapat menikmati aneka hiburan, seperti mengayuh odongodong atau membeli jajanan khas Yogyakarta di kaki lima. Bagi Indri, ia menemukan nuansa Yogyakarta saat berkunjung ke Malioboro dan sekitarnya. Sejauh ini, Malioboro masih cukup bertahan dengan karakternya di saat pengembangan tataruang di beberapa tempat di provinsi ini justru cenderung menjauhkan Yogyakarta dari identitasnya yang otentik (Indri, 2017).
Selain Indri, ada Lilis remaja asli Yogyakarta yang sangat sering menghabiskan waktu untuk menikmati Malioboro. Bagi Lilis, Malioboro tetap menjadi tempat favorit untuk menikmati Yogyakarta. Ditambah dengan adanya program "Jogja Resik," yang mengosongkan Malioboro dari aktivitas berjualan per 35 hari sehingga kawasan ini hanya diperioritaskan untuk para pejalan kaki. Selain ke Malioboro, Lilis juga sering ke Alun-alun Kidul dan Alun-alun Utara. Di Alkid (Alun-alun Kidul), dia tidak hanya sekedar menikmati keindahan suasananya, tapi juga memanfaatkan trek lari di sepanjang trotoar yang melingkar, menggunakan alat-alat olah raga yang tersebar di setiap sudut alun-alun, atau sekedar membuat janji ketemu dengan kawan-kawannya. Baginya, Alkid juga Malioboro adalah tempat yang ramai tapi tenang. Berbeda dengan mol yang cenderung tidak memberikan rasa tenang, tiga kawasan di sekitar kraton tersebut menjadi destinasi wisata yang paling populer di kota Yogyakarta dan masih memberikan rasa aman dan nyaman untuk warga Yogyakarta.

Cerita lain tentang Yogyakarta adalah keberadaan ruang bersama di pinggir rel stasiun Lempuyangan. Belum ada informasi yang eksak sejak kapan kawasan pinggir rel stasiun Lempunyangan menjadi titik berkumpul warga. Akan tetapi bisa dipastikan kawasan ini dipadati masyarakat sepanjang hari, terutama sore. Mereka datang dari pelbagai wilayah Yogyakarta dan sekitarnya. Meskipun mereka berangkat dari kelompok umur, profesi, hobi, dan asal daerah yang relatif beda, tapi alasan mereka nyaris seragam: berwisata di tempat yang murah meriah. Bagi mereka, menonton kereta di pinggir rel stasiun Lempuyangan tidak dipungut biaya dan biasanya sangat diminati oleh anakanak. Seperti dilakukan Anto, yang baru kali kedua ke Lempuyangan. 
"Saya baru dua kali ke tempat ini karena mengikuti kemauan anak. Tadi kebetulan pas mampir dan penasaran dengan pasar tiban yang ada di sini. Tempat ini sangat bagus dikembangkan jadi tujuan wisata kota sehingga tidak hanya wilayahwilayah mainstream seperti Malioboro dan alun-alun. Bagus untuk pariwisata gratis. Bisa jadi alternatif biar tidak selalu ke mall."

Pengalaman Anto hampir sama dengan sebagian besar orang tua yang lebih memilih area pinggir kereta ketimbang mengajak anaknya bermain di pusat perbelanjaan modern. Selain pertimbangan finansial (di mall relatif lebih mahal), juga sensasi yang dirasakan. Hal serupa juga dirasakan Rais, seorang buruh di Yogyakarta. Dia lebih memilih mengajak anaknya menonton kereta yang melintasi rel-rel di stasiun Lempuyangan daripada sang anak bermain gadget atau ke pergi ke mall.

"Pemandangan di mall itu-itu saja. Di pinggir rel, lebih sensasional. Ada kereta yang melintas. Anakanak suka melihat kereta. Bisa mengalihkan mereka dari HP dan bermain di mall yang cukup mahal. Saya ke mall kalau dapat gajian. Sekali ke mall, saya biasanya bisa menghabiskan uang 300 ribuan, untuk beli baju dan main anakanak. Meskipun anak-anak sangat menikmati permainan di mall, tapi akan saja coba alihkan ke sini yang lebih murah dan tidak monoton. Kalau di sini saya paling banter menghabiskan 20 ribu untuk jajan mereka (anak-anak)."

Selain datang ke Lempuyangan, Rais biasanya juga mengajak anaknya ke acara-acara tradisional seperti Sekaten di alun-alun utara dan pasar malam di daerah Sleman. Selain tidak menghabiskan uang yang banyak, Rais juga ingin mengenalkan kepada anaknya seremoni-seremoni kebudayaan. Pengenalan nilai-nilai tradisi sedari kecil diharapkan mampu menepis nilai-nilai baru yang tidak sejalan dengan identitas Yogyakarta sebagai kota budaya.

Sensasi duduk-duduk sambil menunggu kereta yang melintas memberi sensasi tersendiri bagi warga kota. Sebagaimana yang dialami Anung, warga Prambanan pecinta kereta yang masih berstatus sebagai mahasiswa. Sejak 2013, saat dia menjadi mahasiswa baru di Yogyakarta, Anung hampir setiap hari datang ke pinggrir rel kereta di Lempuyangan. Awalnya, dia tertarik datang karena tempat itu menjadi titik keramaian, banyak anak kecil dan pedagang. Sejak itu, dia sangat rajin datang ke tempat ini. Tidak hanya menikmati kereta yang datang dan pergi, ia juga mulai mendokumentasikannya. Dia merasakan pengalaman yang beda jika dibandingkan dengan tempat lain seperti datang ke pusat perbelanjaan. Salah satu sensasinya adalah menyaksikan kereta yang datang dan pergi serta suasana yang menyertainya. Menurut Anung, sensasi itu tidak dapat ditemukan saat melancong ke destinasi wisata modern.

Pengunjung rel Lempuyangan tidak hanya dari wilayah Kota Yogyakarta, tapi juga dari Gamping, kawasan barat Yogyakarta. Sebagaimana keluarga Syaefuddin, pedagang asal Gamping, yang rela membawa keluarganya (istri, anak, bayi) menikmati senja di Lempuyangan. Sejak mereka berpacaran, sudah sering datang ke pinggir rel dan sekarang mereka membiasakan anak-anaknya yang kecil untuk menikmati wisata alternatif itu. Minimal sekali dalam seminggu keluarga ini datang ke Yogyakarta, di Lempuyangan atau di Tugu. Sama dengan alasan pengunjung-pengunjung lain, mereka juga mencari sensasi yang tidak diperoleh di tempat lain. Selain melihat kereta yang lewat, keberadaan pedagang dan penyedia jasa mainan menjadi salah satu magnet anak-anak datang ke Lempuyangan. 


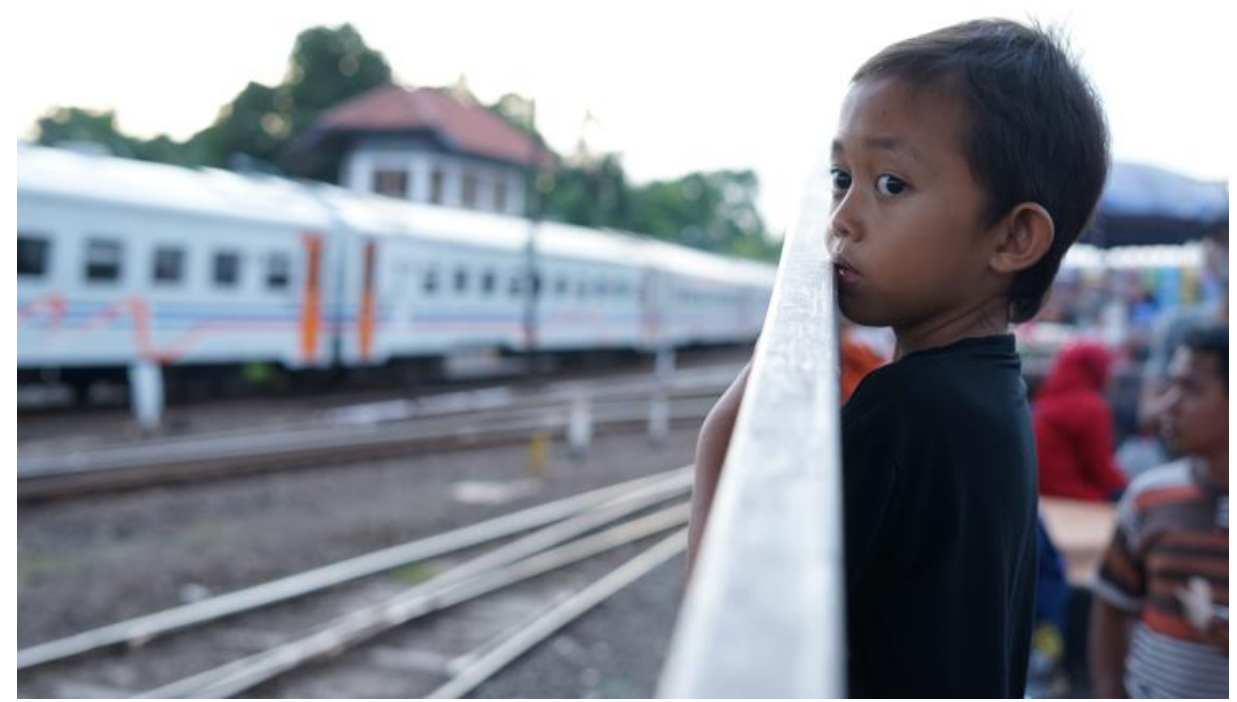

Anak kecil pengunjung Lempuyangan (foto: Gunawan Iskandar/labkom UII)

Selain dipadati pengunjung, Lempuyangan juga dipenuhi pedagang dan penyedia jasa mainan untuk anak-anak. Salah satu pedagang yang selalu membuka lapak dagangannya adalah Halimi. Pria asal Jawa Barat ini sudah menjajakan sate telur puyuh sejak 2006, pasca gempa besar yang melanda Yogyakarta. Hingga kini, 11 tahun setelah itu, Halimi masih menjual telurnya dari jam tujuh pagi hingga jam sembilan malam.

"Dalam sehari biasanya saya menjual 600 sampai 700 telor puyuh. Sejak pagi, saya sudah di sini. Biasanya ada ibu-ibu yang mengantar anaknya sekolah pada mampir ke sini. Mereka biasanya datang dengan motor atau mobil. Semakin hari semakin ramai. Saya tidak pernah jualan di tempat lain."
Selain Halimi, juga ada Lina, penyedia jasa odong-odong asal jalan Magelang. Usahanya sudah dimulai sejak 2009, dan mulai menetap di Lempuyangan sejak 2010. Menempati lahan milik PJKA di Lempuyangan sebagai berjualan bagi Lina terasa gampang-gampang susah.

"Lapak yang digunakan para pedagang dan penyedia jasa permainan adalah lahan milik PJKA. Kami harus 'kulonuwun' dulu untuk memakainya. Sejauh ini sebenarnya tidak diperbolehkan, tapi juga tidak dilarang. Jadi, fleksibel saja." (Lina, 2017). 


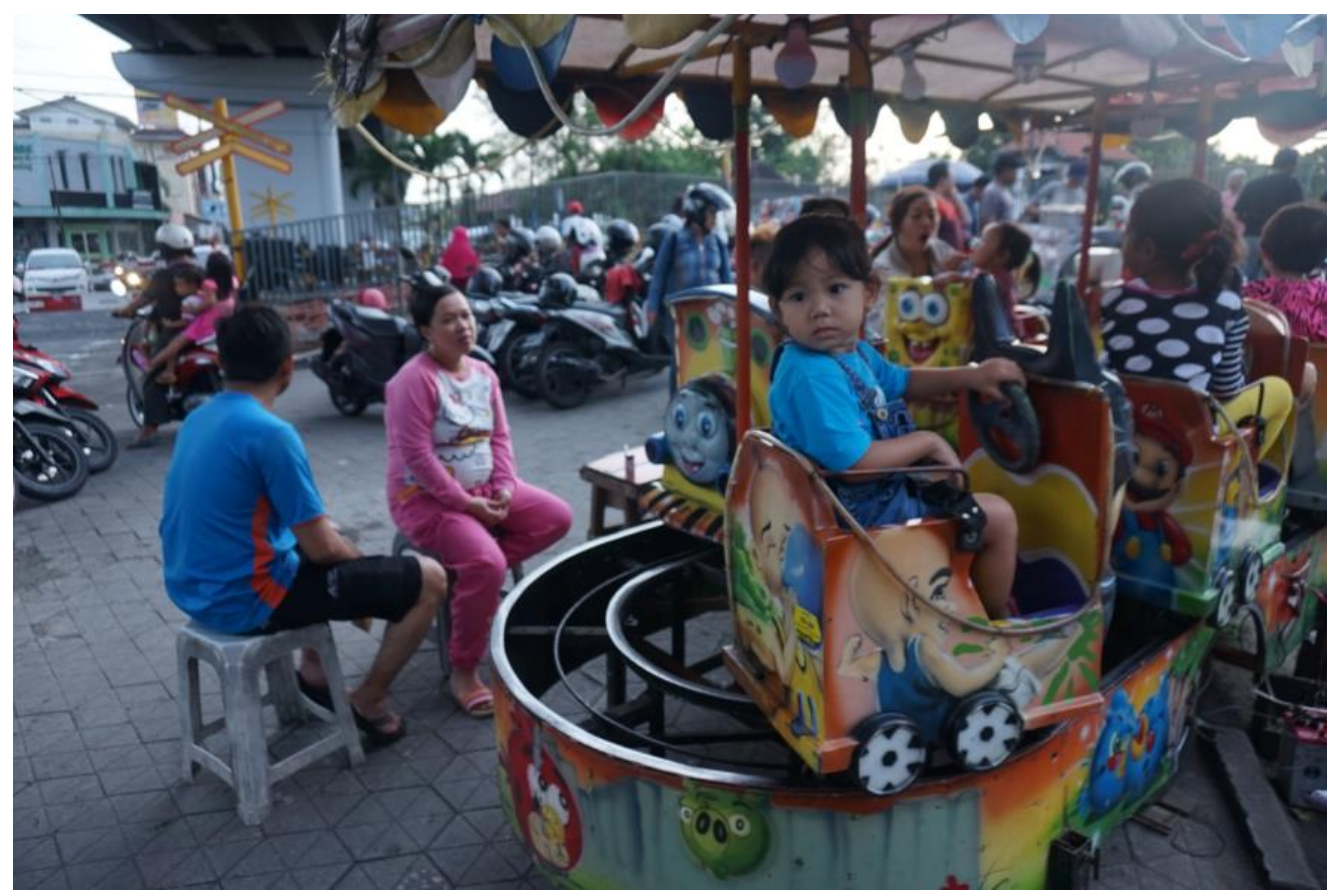

Suasana permainan di Lempuyangan (foto: Gunawan Iskandar/Labkom UII)

Selain mangkal di Lempuyangan, Odong-odong milik Lina juga dimanfaatkan untuk acara lain di Pakualaman atau di tempat lain jika ada warga yang ingin menyewanya. Lina berangkat dari rumah jam empat sore dan pulang sekitar jam sembilan malam. Dalam sehari Lina mentargetkan pendapatan 50 ribu. Sekali menggunakan odong-odong pelanggan harus membayar lima ribu rupiah untuk enam lagu atau bisa diperpanjang dengan biaya tambahan. Jika sepi, pengunjung dapat lebih lama menggunakan odong-odong karena tidak ada antrian. Lina harus bersaing dengan odong-odong lain karena saat ini ada empat odong-odong di sekitar jembatan Lempuyangan. Keempat odong-odong bersaing memperebutkan pengunjung (anak-anak) yang jumlah reratanya sekitar 200 an perharinya. Akan tetapi di masamasa tertentu, seperti musim Sekaten, pengunjung yang datang berkurang.

\begin{abstract}
"Kawasan lempuyangan semakin ramai. Pedagang semakin bertambah. Saling berbagi lahan. Lokasi sangat menentukan. Keberadaan pedagang juga menjadi faktor yang mengundang pengunjung. Tapi sekarang jumlah pedang dan pengunjung juga agak berkurang setelah dibangun taman dan pagar pembatas." (Lina, penyedia jasa odong-odong, 2017)
\end{abstract}

Selain beberapa ruang alternatif di seputaran malioboro dan rel kereta, Yogyakarta juga memiliki galeri seni rupa dan warung kopi alternatif yang dapat dengan mudah diakses warga kota.

Beberapa ilustrasi di atas menunjukkan masih ada ruang-ruang kesenangan yang muncul secara organik maupun artifisial di tengah laju perubahan Kota Yogyakarta. Bagi sebagian warga, area wisata organik seperti di bawah jembatan Lempuyangan sangat penting untuk dipertahankan karena dapat menjadi ruang perjumpaan dan hiburan bagi masyarakat kota, terutama kelompok menengah bawah yang tidak dapat 
mengakses ruang-ruang kesenangan yang disediakan kota. Kehadiran pusat perbelanjaan modern dan apartemen yang semakin masif justru menyertakan pelbagai dampak buruk bagi warga Yogyakarta. Selain ada beberapa konflik terkait dengan efek lingkungan, seperti limbah dan ketersediaan air bersih, kehadiran supermarket dan apartemen juga menimbulkan perubahan tata ruang kota yang tidak terkendali dan berpotensi mrucut dari nilai-nilai-dalam bahasa prokem-ke-Jogja-an. Situasi ini dianggap dapat mengancam keistimewaan Yogyakarta sebagai Kota Budaya dan Pendidikan. Situs-situs konsumerisme mendorong masyarakat menjadi semakin konsumtif dan bergaya hidup hedonis.

Salah satu yang berperan dalam konstruksi ruang kesenangan alternatif adalah kelas menengah kota. Kelas menengah kota juga menjadi kelompok yang, sebagaimana disebut Geertz, memiliki dua kaki. Selain memproduksi, mereka juga menjadi konsumen ruangruang kesenangan. Sebagaimana Anto dan Syaifuddin, pengunjung di area stasiun Lempuyangan yang datang ke tempat itu hanya untuk mencari sensasi yang berbeda. Kecenderungan ini juga terjadi di hampir semua tempat-tempat keramaian yang pada mulanya sangat khas kelompok bawah kemudian menjadi (juga) tempat nongkrong kalangan menengah atas. Angkringan Tugu salah satunya. Pada mulanya, deretan angkringan di dekat stasiun Tugu hanya disambangi oleh kelompok bawah, tapi dalam perkembangannya mulai didatangi oleh para pelancong dan kelompok menengah atas. Saat ini, gaya angkringan Tugu sudah mulai ditiru oleh pelaku baru yang membuka dagangannya di sepanjang jalan Mangkubumi. Kehadiran media sosial mempercepat laju pertambahan jumlah pengunjung yang penasaran dengan tempat-tempat kesenangan di Yogyakarta yang pada mulanya muncul secara organik.
Kelompok kelas menengah kota sangat menentukan perubahan status ruang, melalui pemaknaan atas ruang. Proses pemaknaan terhadap ruang terjadi melalui serangkaian tindakan sosial yang berlangsung di dalamnya. Selanjutnya, konstruksi spasial sangat menentukan berlangsungnya konstruksi sosial sebagaimana pandangan Lefebvreian. Dalam pandangan Lefebvre, konstruksi terhadap ruang memiliki muatan ideologis sehingga keberadaannya sangat diperebutkan oleh beragam elemen. Kehendak untuk berkuasa atas ruang menyebabkan ruang menjadi area persabungan terbuka yang meniscayakan kepelbagaian kekuatan bertemu dan bertarung. Akibatnya, kelompokkelompok pemodal memiliki peluang yang sangat besar untuk memenangi setiap "perkelahian". Kemenangan kelompok pemodal menyebabkan ancaman bagi kelompok miskin kota yang tidak sanggup mengakses kesenangan 'berbayar' yang ditawarkan kelompok pemodal. Ketidakasanggupan itu menyebabkan kelompok menengah bawah di perkotaan mencoba mengkreasi ruang baru, baik yang tumbuh secara organik maupun yang artifial.

Produksi ruang alternatif juga dipicu oleh ketidakberdayaan kelompok miskin kota yang berjarak dari pola konsumtif kalangan kelas menengah atas. Ruang-ruang kesenangan yang muncul secara organik dimanfaatkan mereka untuk menemukan kesenangan alternatif. Bertandang ke mal sebagaimana pengalaman Rais hanya di waktu tertentu saja (saat gajian). Begitu juga dengan Anung yang hanya menjadikan mal sebagai intermezzo di antara hobinya sebagai pencinta kereta api meskipun godaan pusat-pusat perbelanjaan sangat besar.

Kesanggupan warga untuk bernegosiasi dapat menjelaskan posisi subyek Zizekian yang selalu menyisakan 
ruang kosong yang terbuka. Subjektivitas modern ala Zizek memampukan subjek menjadi kompatibel dengan ruang kebudayaan yang melingkupi. Subjek digdaya saat berhadapan dengan dinamika budaya yang cair dan tak pernah konstan. Subjek memiliki -sekaligus-yang nyata (the real), yang Imajiner, dan Yang Simbolik (multiciple subject) (Zizek, 1999:195). Yang Nyata dalam subjek akan tetap bertahan meskipun selalu mengalami simbolisasi di dalam tatanan simbolik (Zizek, 1993:21). Identitas kewargaan akan terus mengalami perubahan (displacement) ketika ia berada dalam ruang simbolik yang dinamis (the Big Other), tetapi proses transformasi itu tidak mengubah subjek sepenuhnya. Selalu ada "the Real" yang tetap melekat dan bertahan pada subjek. Pemahaman tentang subjek ini pula yang digunakan untuk menjelaskan subjek yang bertahan dalam menghadapi bombardir bujuk rayu kekuatan kapitalisme (yang Simbolik).

Respons subjek untuk berkelit dari yang Simbolik -objek-objek yang dihasrati-disebut sebagai tindakan radikal. Sebagaimana kita menegasikan dan menihilkan segala yang ingin dikonsumsi. Zizek menyebutnya sebagai psychotic subject (Zizek, 2008: 186) ketika subjek sanggup menahan diri untuk berjarak dengan tatanan simbolik yang interpelatif.

Sikap ini, menurut Zizek, cukup jitu untuk menghadapi bentuk kapitalisme kontemporer yang disebutnya sebagai kapitalisme kultural atau capitalism with human face (Zizek, 2009:52). Bentuk kapitalisme yang menawarkan kesenangan (enjoyment) dapat disejajarkan dengan bentuk kapitalisme mutakhir ini. Kota sebagai panggung kontestasi akan selalu memberi ruang bagi subyek yang mengalami interpelasi untuk berpacu dalam sirkuit konsumerisme tanpa akhir.
Raut kapitalisme kontemporer yang ditampilkan oleh kota menjadi keniscayaan yang muskil untuk ditampik. Dengan demikian, bentuk-bentuk eksklusi yang terjadi harus dihadapi secara taktis. Sebagaimana pandangan De Certeau, dalam masyarakat kapitalisme kontemporer, setiap orang adalah konsumen. Konsumsi, menurut Certeau, menjadi satu-satunya jalan untuk memperoleh sumber-sumber kehidupan, baik yang bersifat material fungsional ataupun semiotika kultural (de Certeau, 1984). Dalam corak yang kedua, barang konsumsi tidak selamanya material, tapi lebih ke bentuk tindakan budaya. Konsumsi selalu memproduksi makna dan budaya. De Certeau percaya bahwa konsumsi merupakan serangan taktis terhadap tatanan simbolik. Bagi de Certeau, interpelasi untuk menarik perhatian konsumen dan mendorong konsumsi sama artinya dengan menciptakan penipuan, perampokan, atau la perruque. Orang-orang yang dibujuk oleh mekanisme interpelatif menyimpan potensi untuk melakukan serangan balik, sebagai penipu. De Certeau merujuk pada penelitiannya terhadap masyarakat di Brazil dalam menghadapi rongrongan kapitalisme. Di sana, para remaja memanfaatkan pusat perbelanjaan sebagai ruang pribadi untuk bertemu (meeting point), memanfaatkan fasilitas mal (AC) saat cuaca ekstrem, dan dapat menemukan ide-ide kreatif terkait fashion (Fiske: 45).

Tindakan taktis dalam menghadapi ruang-ruang konsumerisme justru belum banyak terlihat dalam gaya hidup kelas menengah di Indonesia. Sebagian besar kelas menengah baru Indonesia (masih) lebih tertarik untuk mengonsumsi barangbarang komersial sebatas sebagai simbol status sosial (symbolic value). "Insiden Belaggio" di Mal Pasific Place, Jakarta, 25 November 2011 menjadi potret yang menarik bagaimana kelas ini bertaruh demi mengonsumsi barang komoditas 
sebagai penopang gaya hidup. Peluncuran telepon pintar Blackberry seri Bold 9790 (Belaggio), memicu terjadinya antrian panjang yang berujung pada insiden yang mengakibatkan 90 orang pingsan (SKH Kompas, 26 November 2011). Sebenarnya, fenomena produk komoditas semacam ini tidak hanya khas Indonesia. Hal serupa juga terjadi di beberapa negara. Antrean serupa juga terjadi di AS, Hongkong, dan Singapura ketika Ipad seri terbaru diluncurkan. Kecenderungan generik perilaku kelas menengah ini menggugat kredo kelas menengah sebagai "agent of change". Di sinilah, kelas menengah tidak dapat sepenuhnya menjadi tumpuan dalam perubahan politik kewargaan dalam memperjuangkan ruang yang memiliki nilai kepublikan.

Kegagalan kelas menengah perkotaan untuk menjadi akselerator perubahan politik turut menggeser lokus wacana kewargaan dalam konteks pemenuhan hak-hak kesejahteraan. Belajar dari Korea Selatan, kesejahteraan yang terjadi tidak hanya digerakkan oleh kelas menengah dan industri besar, tapi juga peran kelas menengah perdesaan (Prisma, 2012: 67). Park Chung Hee, pemimpin Korea Selatan saat itu, menganggap kelas menengah perdesaan menjadi basis politik yang bisa mendesak kaum kapitalis dan industrialis memenuhi persyaratan ekonomi dan keuangan yang memberi keuntungan bagi kesejahteraan rakyat. Kelompok-kelompok menengah perdesaan, juga kelompok-kelompok masyarakat di luar luar kategori kelas menengah perkotaan, sebagaimana pengalaman di beberapa tempat seperti yang digambarkan De Certaeu (1984) adalah pasukan gerilya yang menyerang kelompok berkuasa. Seperti yang berlangsung di Alkid Yogyakarta, ketika orang-orang menemukan dinamika di ruang yang awalnya tidak memiliki kapasitas estetik sebagai tempat bersenang-senang. Pun, munculnya "pasar tiban" di beberapa kawasan, seperti Sunday Morning di kawasan Universitas Gadjah Mada Yogyakarta, juga beberapa kota lain, seperti Bandung, Malang, Surabaya, dsb.

Kesadaran warga kota untuk memproduksi dan mengonsumsi ruangruang kesenangan alternatif, baik secara organik maupun artifisial, bisa ditandai sebagai ekspresi perlawanan diam-diam. Ketika warga kota tidak sanggup menjangkau situs-situs turisme dan konsumerisme, mereka mengkreasi ruangruang baru sebagai space of enjoyment. Menggunakan pandangan De Certaeu (1984:18) tentang perlawanan populer yang dilakukan dengan pengecohan sebagai cara warga kota melawan kebijakan pemerinta lokal. Melalui produksi ruang kesenangan alternatif, masyarakat memberi isyarat tentang kemandirian dan ketidakbergantungan dengan kekuatan simbolik yang besar. Sebagaimana kreasi ruang yang terjadi di Malioboro, Jembatan Lempungan, Alkid, Geneng dsb. Ruang kesenangan alternatif yang dibangun warga menunjukkan survivalitas untuk sanggup berkelit dari kekangan kekuatan besar.

Di tengah pudarnya harapan terhadap kelas menengah perkotaan, keberadaan kelas menengah di Yogyakarta, terutama seniman dan intelektual, masih memberi peluang yang cukup besar dalam mengkreasi ruang-ruang kesenangan alternatif. Dengan modalitas dan jeringan yang dimiliki, kelas menengah dapat memproduksi ruang-ruang alternatif baru sebagai sarasa penyadaran warga kota maupun pinggiran kota. Munculnya kampung cyber di kawasan Tamas Sari, aktivisme seni jalanan di Desa Geneng (Geneng Street Art Project), galeri, pameran dan pagelaran seni, serta menjamurnya ruang-ruang diskusi yang embedded dengan denyut kehidupan urban cukup menstimulasi harapan pada 
kelompok ini untuk memproduksi ruangruang kesenangan alternatif yang berpihak pada warga.

\section{Kesimpulan}

Kehadiran ruang-ruang publik alternatif, tempat sebagian masyarakat meluangkan waktu, mengonsumsi kesenangan seperti yang terlihat di pinggir-pinggir rel kereta, tempat-tempat kuliner di sepanjang trotoar kota, alunalun kota, ataupun pertunjukan seni di pinggiran kota menyimpan jejak panjang dari proses politik yang tak singkat. Ruangruang yang muncul secara organik ataupun artifisial dapat bertransformasi menjadi ruang publik ketika warga dapat menemukan ruang yang mempertemukan kepelbagaian identitas dan gagasan. Keberadaan ruang-ruang kesenangan baru yang dikreasi sekaligus dikonsumsi di beberapa titik di Kota Yogyakarta dapat menjadi destinasi alternatif bagi warga dalam menikmati kota. Warga tidak selalu terjebak dalam ruang-ruang konsumerisme yang memaksa mereka dalam perlombaan gaya hidup yang destruktif.
Aktivitas warga untuk berkumpul, menonton kereta yang melintas; menikmati keramaian alun-alun menunjukkan jejak "pertarungan" yang sangat politis, yang di dalamnya berlangsung proses negosiasi yang intens. Sekelompok masyarakat yang menikmati ruang kesenangan alternatif di Yogyakarta tidak muncul secara tiba-tiba tapi melalui proses negosiasi dengan pihak-pihak otoritatif. Keberadaan ruang kesenangan "baru" ini cukup strategis menjadi alat negosiasi yang dapat bertransformasi menjadi ruang publik yang dapat menjadi simpul bagi munculnya kesadaran bersama untuk memperjuangkan kepentingan-kepentingan publik yang lebih luas. Ruang kesenangan alternatif yang dibangun warga menunjukkan survivalitas untuk sanggup berkelit dari kekangan kekuatan besar. Kelas menengah, terutama seniman dan intelektual, memiliki andil yang cukup besar dalam mengkreasi ruang-ruang kesenangan alternatif. Dengan modalitas dan jejaring yang dimiliki, kelas menengah dapat memproduksi ruang-ruang alternatif baru sebagai sarasa penyadaran warga kota. 


\section{DAFTAR PUSTAKA}

Debord, Guy. Comment on the Society of Spectacle. London \& New York: Verso, 1990.

Fiske, John. Memahami Budaya Populer. (terj dari Undestanding Popular Culture). Yogyakarta: Jalasutra, 2011

Lefebvre, Henri. The Production of Space. Victoria: Blackwell Publishing, 1974

Lange, Hellmuth.(eds.). The New Middle Classes: Globalizing Lifestyles, Consumerism, and Environmental Concern. New York: Springer, 2009

Marco Kusumawijaya dalam "Jakarta, Sang Metropolis" yang dimuat dalam Jurnal Kalam 2002.

Mas'oed, Mohtar, S.Rizal Panggabean, dan Najib Azca. "Sumber-sumber Sosial bagi Sivilitas dan Partisipasi: Kasus Yogyakarta, Indonesia" dalam Robert Hefner (ed.). Politik Multikulturalisme. Yogyakarta: Kanisius \& Impulse, 2007

Miles, Steven. Consumerism as a Way of Life. London: SAGE Publications, 1998

Rajendra Singh. Social Movement: Old and New: a Post-Modernist Critique, 2001.

Robert, Robertus. Manusia Politik: Subyek Radikal dan Politik Emansipasi di Era Kapitalisme Global Menurut Slavoj Zizek. Jakarta: Marjin Kiri, 2010

Zizek, Slavoj. The Ticklish Subject. The Absent Centre of Political Ontology. London \& New York: Verso, 1999,
Zizek, Slavoj. Tarrying with Negative. Durham: Duke University Press, 1993

Harian Kompas, 26 November 2011, hlm. 1 dan 5 .

Jurnal Prisma Vol 31 tahun 2012

\section{Wawancara}

Wawancara dengan Anung (2017)

Wawancara dengan Heru (2017)

Wawancara dengan Indri (2017)

Wawancara dengan Lilis (2017)

\section{Internet:}

- kurunganhttps://teamtouring.net/ nonton-kereta-api-lewat-dibawah-jembatan-layanglempuyangan.html.

- https://tirto.id/risiko-dan-nasibkota-yogyakarta-di-usia-26otahun-bR6N. diakses tanggal 15 Juli 2018.

- https://tirto.id/warga-yogyamenolak-pembangunan-hotel-danapartemen-csjG

- Http://www.merdeka.com/peristi wa/goyang-yogya-24-tahundangdutan-purawisata-akhirnyatutup.html;

http://jogjanews.com/purawisataakan-ditutup-suasana-berkabunguntuk-musik-dangdut-jogja;

http://www.koransindo.com/node/313215, diunduh pada 17 Juli 2013 
Jurnal komunikasi, Volume 13, Nomor 1, Oktober 2018 